\title{
Effect of Prostaglandin $\mathrm{F}_{2 \alpha}$ on Estrus Synchronization in Crossbred and Indigenous Cows on Smallholder Dairy Farms in Mazabuka, Zambia
}

\author{
Kavwanga E.S. Yambayamba ${ }^{1}$, Yvonne Mwanza $^{2}$ \\ ${ }^{1}$ School of Agriculture and Natural Resources, Mulungushi University, Kabwe, Zambia. \\ ${ }^{2}$ Kariba Harvest Limited, Siavonga, Zambia.
}

\begin{abstract}
A study involving 35 Friesian x Indigenous (CROSSBRED) and 35 Indigenous (INDIGEN) nonlactating multiparous cows was conducted in Mazabukato investigate the effect of Prostaglandin $F_{2 \alpha}\left(P G F_{2 \alpha}\right)$ on estrus synchronization. On day 0 , the cows were intramuscularly injected with $2 \mathrm{ml}$ of $P G F_{2 a}$ and observed for estrus. On day 11, the injection was repeated in those cows that did not respond to the first injection. The Estrus Response (\%) and the Response Time (hours) were statistically compared between the two groups of cows. Twelve (34\%) CROSSBRED and five (14\%) INDIGEN cows came into estrus following administration of $P G F_{2 \alpha}$. While the Estrus Response was low in both groups of cows, the number of responsive CROSSBRED cows was numerically higher than that of INDIGEN cows. The Response Time was, however, similar (P>0.05) in both groups of cows. It is concluded that estrus synchronization with PGF $F_{2 \alpha}$ had more effect in CROSSBRED cows than in INDIGEN cows. For practical purposes, however, the apparent greater effect of PGF $2 \alpha$ in CROSSBRED cows was not significant to warrant recommendation. This technique is therefore not recommended for smallholder dairy farmers under the current management levels. Further research on how to improve the effectiveness of estrus synchronization is recommended.
\end{abstract}

Keywords: Smallholder dairy, estrus synchronization, prostaglandin, Mazabuka.

\section{INTRODUCTION}

Animal production is considered as the main component of agricultural development in most parts of Sub Saharan Africa [1]. Dairy production, in particular, is a long-term investment and potentially offers an all -year round revenue for smallholder farmers. The smallholder dairy sector in Zambia offers great potential for improvement of milk production as it holds the larger number of cattle than the commercial sector. In practice, however, the smallholder sector contributes no more than half of the national production of milk [2]. Generally, the sector has not performed well due to a number of factors including lack of clear government policy, limited capital, insufficient inputs and poor marketing infrastructure.

In recent years, however, there has been increased level of production of milk due to an increase in the number of participating smallholder farmers [3]. While the interest in smallholder dairy farming has increased, inefficiency in the management of the dairying business has been a big challenge. The type of cattle used in this business (for example indigenous breeds) has also hampered significant progress of the smallholder dairy sector. Since the 1980s, however, there have been efforts to upgrade the indigenous breeds by crossing them with pure Friesian bulls. In the past 20 years or so, Artificial Insemination (AI) has taken centre stage among the smallholder dairy producers [4] although some are reluctant to take up the technology. Notwithstanding this, the major factor limiting optimum reproductive performance on smallholder dairy farms is failure to detect estrus in cows. Consequently, there are stakeholder efforts to formally introduce estrus synchronization as a tool to support AI.

In Mazabuka District where several smallholder farmers rear both indigenous and crossbred cows, reports by technicians involved in estrus synchronization trials using prostaglandins indicate that there is great variation in terms of response between the local and crossbred animals (V. Simoongwe, Personal Communication, 2014). However, no research has been done to scientifically test the different breeds of cattle. There is therefore a dearth of information regarding the effect of prostaglandins on estrus synchronization in cows reared on smallholder dairy farms. The objective of this study was therefore to evaluate the effect of Prostaglandin $F_{2 \alpha}$ on crossbred and indigenous cows in Mazabuka District. 


\section{MATERIALS AND METHODS}

\subsection{Study Area and Selection of Animals}

The study was conducted in Mazabuka ( $\left.15^{\circ} 52^{\prime} 0^{\prime \prime} \mathrm{S}, 27^{\circ} 46^{\prime} 0^{\prime \prime} \mathrm{E}\right)$ in the Southern Province of Zambia. This area is located on a plateau (agro climatic zone IIa), with annual rainfall of 800-1000 $\mathrm{mm}$ and an average temperature of $19-26^{\circ} \mathrm{C}$. This area was chosen because of the large number of smallholder farmers participating in the dairy production scheme. The cows, belonging to smallholder dairy farmers, were selected from four different locations within Mazabuka, namely, Munenga, Dumba, Ngwezi and Lubombo.

A total of 70 non-lactating multiparous cows $(5 \pm 1.5$ years old) were selected, 35 crossbred cows (CROSSBRED) and 35 indigenous cows (INDIGEN). Targeted sampling was used to select cows to be included in the study, in order to ensure that the animals were similar in body condition. Body Condition Scoring (BCS) was done using the scale by Rodenburg [5] and only those with a BCS of 3.0-4.0 were selected. Pregnancy diagnosis was done in all cows by experienced technicians to ensure that only the empty ones were selected for the study. The study was done during the months of high rainfall, January and February, to ensure that there was enough pasture for the animals.

\subsection{Estrus Synchronization and Data Collection}

All the cows were injected intramuscularly with $2 \mathrm{ml}$ each of $\mathrm{PGF}_{2 a}$ and continuously observed for overt estrus. On day 11, the injection was repeated in the cows that did not respond to the first injection. The total number of cows that came into estrus following administration of the prostaglandin and the Response Time (hours) were recorded.

\subsection{Statistical Analysis}

Genstat (version 13.1) [6] was used to statistically analyze the data. The number of cows that responded to the prostaglandin was computed into percentages (Estrus Response). Response Time (hours) was statistically analyzed to compare the two treatments using a $t$-test.

\section{RESULTS AND DISCUSSION}

\subsection{Estrus Response}

Twelve (34\%) CROSSBRED cows and five (14\%) INDIGEN cows responded to the estrus synchronization (Table 1). For practical purposes, it was noted that the Estrus Response in both types of cattle was low, although it was numerically higher in the CROSSBRED cows compared to the INDIGEN cows. The generally low Estrus Response recorded in the present study is not consistent with other studies. For example, Patil and Pawshe [7] who induced estrus in crossbred cows and heifers using $\mathrm{PGF}_{2 \alpha}$ reported that $62.5 \%$ of the cows responded positively. Similarly, Kebede et al. [8] who administered $5 \mathrm{ml}$ of $\mathrm{PGF}_{2 \alpha}$ to local cows and heifers in a study conducted in three districts of Bahir Dar Milk Shed reported high Estrus Response (89.3\%), although the conception rate was low (13.7\%). The authors concluded that $\mathrm{PGF}_{2 \alpha}$ was very effective in both cows and heifers. Apparently, the perception of the farmers in the three districts was also that $\mathrm{PGF}_{2 \alpha}$ was effective in triggering estrus but that the pregnancy rate was low due to severe feed shortage. Malik et al. [9] who studied the effects of the route of $\mathrm{PGF}_{2 \alpha}$ administration (intramuscular vs intra-uterine) in Bali and Crossbred cattle also found a relatively high Estrus Response in Bali cows (41\%) and Crossbred cows (45\%) after the first intramuscular injection; the response increased to $80 \%$ and $83 \%$, respectively, following the second injection. A recent study in Northern Ethiopia [10] showed that the mean Estrus Response in local and Holstein Friesian cows was $91.67 \%$.

Table1. Estrus Response (\%) of the CROSSBRED and INDIGEN cows administered with PGF ${ }_{2 \alpha}$

\begin{tabular}{|l|c|c|c|c|}
\hline Treatment & No. of cows & No. of responsive cows & \% Response & \% Non-response \\
\hline INDIGEN & 35 & 5 & 14 & 86 \\
\hline CROSSBRED & 35 & 12 & 34 & 66 \\
\hline
\end{tabular}

The low Estrus Response in both groups of cows in the present study could possibly be explained from the view point of low management levels by smallholder dairy farmers in the study area. Although the study was done in the rainy season when there was supposedly more pasture available, lack of supplementation, as generally observed among many smallholder farmers, could be associated with low Estrus Response. It has been observed that flushing cows with high energy feed following administration of synchronization drugs results in very high response [11]. 
The difference in the Estrus Response between INDIGEN and CROSSBRED cows was not surprising, since the latter have genes of Bos taurus cattle (Holstein Friesian) which have been reported to respond better to $\mathrm{PGF}_{2 \alpha}$ administration [12]. Given that several studies have reported high estrus response to $\mathrm{PGF}_{2 \alpha}$, the big differences between the INDIGEN and CROSSBRED cows in the present study could be explained from the difficulty in detecting estrus in the former (Bos indicus) compared to the latter. Bo et al. [13] and Galina and Orihuela [14] observed that the low intensity and short duration of signs of estrus in Bos indicus indicated that the work needed to correctly detect this period in these cows was a difficult one and also imprecise. According to Bo et al. [13], it has been speculated that one of the reasons why the female Zebu presents weak signs of estrus is because the follicular diameter is generally smaller than in the Bos taurus. To this effect, it is likely that a direct relationship exists between the follicular diameter and the quantity of estrogen that is synthesized by the cells of the theca interna [15] and this possibly affects the intensity of the signs and sexual receptivity [16]. More evidence-based research, however, needs to be done to ascertain these arguments.

\subsection{Response Time}

There was no significant difference $(\mathrm{P}>0.05)$ between CROSSBRED and INDIGEN cows in terms of time taken to respond to estrus synchronization (Table 2). The non-statistical difference was largely due to small numbers of cows that responded in both groups of cattle. However, numerically the INDIGEN cows tended to respond slower than the CROSSBRED cows, although generally it may be stated that the present results showed long intervals between administration of $\mathrm{PGF}_{2 \alpha}$ and the actual signs of estrus. Other studies have reported shorter intervals; for example, Lemaster et al. [17] reported that $60 \%$ of crossbred cows used in their study showed estrus 48-72 hours after PGF $_{2 \alpha}$ injection. Kebede et al. [8] also reported an average of 51 hours following administration of $\mathrm{PGF}_{2 \alpha}$ in local cows. Lamb et al. [18] noted that the average interval from injection of prostaglandin to estrus was usually 60 to 72 hours. Variation in the time taken to estrus is created in part by differences among cows in the rate of regression of the corpus luteum following treatment. The interval from prostaglandin treatment to estrus has also been related to the time required for an ovulatory follicle to develop [19]. Hence, although estrus is synchronized within a 5-day period following prostaglandin treatment, the precision of the synchrony of estrus is reduced by variation due to differences in the stage of follicular development at the time of treatment.

Table2. Mean Response Time (hours) of CROSSBRED and INDIGEN cows to estrus synchronization using $P G F_{2 \alpha}$

\begin{tabular}{|l|c|c|c|}
\hline Treatment & No. of responsive cows & Response Time \pm SE & P \\
\cline { 1 - 3 } INDIGEN & 5 & $102.0 \pm 6.0$ & \multirow{2}{*}{0.2} \\
\cline { 1 - 3 } CROSSBRED & 12 & $84.0 \pm 15.5$ & \\
\hline
\end{tabular}

\section{Conclusion}

It is concluded that estrus synchronization using the $\mathrm{PGF}_{2 \alpha}$ protocol only is not a viable technique to be used in either local or crossbred cows among the smallholder dairy farmers in Mazabuka. A lot needs to be done particularly with regard to management of the dairy cattle under the care of the smallholder farmers. Further research is recommended to determine the factors that could significantly affect the estrus synchronization and the subsequent success of an efficient AI programme.

\section{ACKNOWLEDGEMENTS}

We are indebted to smallholder dairy farmers who willingly allowed research to be done on their animals. Thanks are due to Mr. Vincent Simoongwe and staff at National Artificial Insemination Centre (Mazabuka) for their technical support. We also thank Dr. Davis Lungu and Mr. Martin Sampa for help with statistical analysis. The research was made possible through financial assistance from the Department of Livestock Development through the Ministry of Agriculture and Livestock.

\section{REFERENCES}

[1] Gizaw Y., Bekana M. and Abayneh T., Major reproductive health problems in smallholder dairy production in and around Nazareth town, Central Ethiopia. VetOn-line, The International Journal. Retrieved August 30, 2016, from http://dx.doi.org/10.1016/j.yhbeh.2007.03.025. 
[2] World Bank. What would it take for Zambia's beef and dairy industries to achieve their potential? The World Bank Report (2011). Retrieved September 7, 2016, fromhttp://siteresources.worldbank.org/INTZAMBIA/Resources/beef-and-dairy-summarynotes(online-copy).pdf.

[3] Mumba C., Pandey G.S. and van der Jagt C., Milk production potential, marketing and income opportunities in key traditional cattle keeping areas of Zambia. Livestock Research for Rural Development, Volume 25, Article \#73 (2013). Retrieved September 7, 2016, from http://www.lrrd.org/lrrd25/4/mumb25073.htm.

[4] Mwambilwa K., Yambayamba K.E. and Simbaya J., Evaluation of the reproductive performance and effectiveness of artificial insemination on smallholder dairy farms in Zambia. Scholarly Journal of Agricultural Science. 3(10), 391 (2013).

[5] Rodenburg J., Body condition scoring of dairy cattle. Ministry of Agricultural, Food and Rural Affairs Factsheet. Ontario, 2004. ISSN 1198-712X. Retrieved September 5, 2016, from http://www.omafra.gov.on.ca/english/livestock/dairy/facts/00-109.htm.

[6] GenStat Release 13.1, VSN International Ltd (2010).

[7] Patil S.R. and Pawshe C.H., Estrus induction and fertility following single dose of Prostaglandin $\mathrm{F}_{2}$ alpha in crossbred cows and heifers. Indian Journal of Animal Reproduction. 32(2), 61 (2011).

[8] Kebede A., Zeleke G., Ferede Y., Abate T. and Tegegne A., Prostaglandin (PGF2 $\alpha$ ) based oestrous synchronization in postpartum local cows and heifers in Bahir Dar Milkshed. International Journal of Pharma Medicine and Biological Sciences. 2, 37 (2013).

[9] Malik A., Gunawan A. Jaelani A., Budirahman R. and Erlina S.,Comparison of Estrus Synchronization with Application of Prostaglandin F2 $\alpha$ Intrauterine and Intramuscular in Bali and Crossbred-Ongole Cattle. Pakistan Veterinary Journal. 33, 446 (2013).

[10] Gebrehiwot G., Gebrekidan B., Weldegebriall B., The effect of one shot prostaglandin on estrus synchronization of Local and Holstein Friesian cattle in and around Wukro Kilte Awulaelo District, Northern Ethiopia. Journal of Biology, Agriculture and Healthcare. 5, 99 (2015).

[11] Rahman M.S., Khan M.K.I. and Bilkis T., Effect of flushed feeding and age on estrus synchronization and conception rate of Holstein $\times$ Local Crossbred cows after using analogue GnRH and Prostaglandin F2 $\alpha$ hormone. Iranian Journal of Applied Animal Science. 4(3), 493 (2014).

[12] Alvarez P., Spicer L.J., Chase C.C. Jr, Payton M.E., Hamilton T.D., Stewart R.E., Hammond A.C., Olson T.A. and Wettemann R.P., Ovarian and endocrine characteristics during an estrus cycle in Angus, Brahman and Senepol cows in a subtropical environment. Journal of Animal Science.78, 1291 (2000).

[13] Bo G.A., Baruselli P.S. and Martínez M.F., Pattern and manipulation of follicular development in Bos indicus cattle. Animal Reproduction Science. 78, 307 (2003).

[14] GalinaC.S. and Orihuela A., The detection of estrus in cattle raised under tropical conditions: What we know and what we need to know. Hormones and Behavior. 52, 32 (2007).

[15] Bridges P.J. and Fortune J.E., Characteristics of developing prolonged dominant follicles in cattle. Domestic Animal Endocrinology. 25, 199 (2003).

[16] Van Eerdenburg F.J., Karthaus D., Taverne M.A., Merics I. and Szenci O, The relationship between estrous behavioural score and time of ovulation in dairy cattle. Journal of Dairy Science. 85, 1150 (2002).

[17] Lemaster J.W., Yelich J.V., Keupfer J.R., Fullenwider J.K., Barnett C.L., Fanning M.D. and Seph J.F., Effectiveness of GnRH plus prostaglandin $\mathrm{F}_{2 \alpha}$ for estrus synchronisation in cattle of Bos indicus breeding. Journal of Animal Science. 39, 309 (2001).

[18] Lamb G. C., Stevenson J.S., Kesler D.J., Garverick H.A., Brown D.R. and Salfen B.E., Inclusion of an intravaginal progesterone insert plus GnRH and prostaglandin F2alpha for ovulation control in postpartum suckled beef cows. Journal of Animal Science.79, 2253 (2001).

[19] Murugavel M., Yaniz J.L., Santolaria P., Lopez-Bejar M. and Lopez-Gatius I. (2003). Prostaglandin based estrus synchronization in postpartum dairy cows: An Update. The International Journal of Applied Research in Veterinary Medicine. 1, (2003). Retrieved September 1, 2016, from http://www.jarvm.com/articles/Vol1Iss1/LOPEZDJVM.htm. 